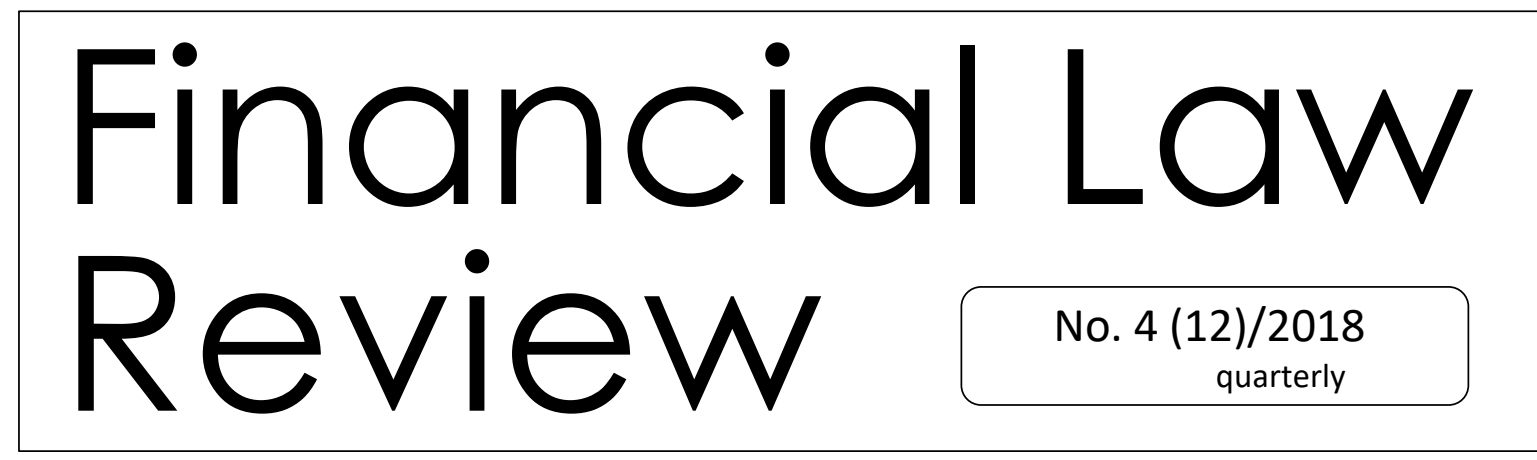

UNIVERSITY OF GDAŃSK • MASARYK UNIVERSITY • PAVEL JOZEF ŠAFÁRIK UNIVERSITY • UNIVERSITY OF VORONEZH http://www.ejournals.eu/FLR

\title{
TAX SPARING CREDIT CLAUSES AND ADVANCE PRICING AGREEMENTS AS IMPORTANT INSTRUMENTS FOR TAX OPTIMIZATION \\ DOMINIKJ. GAJEWSKI*
}

\begin{abstract}
The article is devoted to instruments used by international holding companies in their tax optimization strategies. Some of the most commonly adopted instruments include: tax sparing credit clauses and advance pricing agreements. They are particularly frequently used by related entities operating on the territory of the European Union. The article presents an analysis of these constructions with particular indication of tax effects that have a significant influence on reduction of tax liabilities of related entities operating in various residences for tax purposes. The author demonstrates how these instruments can be adopted in various ways, which are often extremely different from the legislator's intention.
\end{abstract}

Key words: tax sparing credit clauses, advance pricing agreements, holding, optimalization

JEL Classification: K21, K34

*PhD, Warsaw School of Economics (Poland); email: dominik.gajewski@sgh.waw.pl 


\section{General Comments}

Tax avoidance is a common phenomenon in international tax law, which takes the form of understatement of public income appertaining to the state. Tax avoidance boils down to artificially reducing tax liability to a level where taxation is the lowest. Then a particular situation is adjusted to a situation that is the most beneficial for the taxpayer. International holding companies often make use of this, e.g., by making apparent (artificial) divisions of holding structures. Transfer pricing is also a popular platform that holding companies use to optimize taxation.

Abuse of transfer pricing most commonly consists in transferring incomes of related entities by way of carrying out sales of goods or services under non-market conditions to be able to apply preferential taxes to incomes. Some of the phenomena aimed at optimization of taxation imposed on international holding structures within the framework of transfer pricing are: tax sparing credit clauses and advance pricing agreements.

\section{Tax-sparing Credit Clauses}

With respect to the issue of transfer pricing, some phenomena have emerged that may be exploited by international holding companies for the purpose of tax optimization. It is very common for entities making cross-border settlements to use transfer pricing to illegally avoid taxation.

Instances of transfer-pricing abuse most frequently consist of shifting incomes among associated companies by using non-market conditions in trade in goods or services to create income that is entitled to tax benefits [Williamson 1991: 139-140]. One phenomenon that involves the use of transfer pricing and that leads to tax optimization for international holding structures is an instrument referred to as the tax-sparing credit.

The tax-sparing credit is a clause contained in most AADTs. Essentially, the clause works as follows: a developed country protects tax benefits that developing countries offer to investors (holding companies) who are subject to full tax liability in the developed state (where they have their registered offices). The tax-sparing credit is based on a mechanism that consists of developing countries offering tax incentives to foreign investors, such as reductions in tax rates, tax relief, or exemptions. A developed country that is a party to an AADT with a developing country allows an entity that is a resident of the developed country to save the income generated from sources located in the developing country, where it is subject to preferential tax treatment. The result of the situation presented above is that the developed state grants a tax credit to an investor of the amount of tax equal to or greater than that imposed by the developing country. Introduction of the tax-sparing credit instrument to an AADT may assume various forms [Scheuneumann 2006: 56]. The state in 
which an investor has a registered office may offer exemption from tax that the source state might collect pursuant to general statutory laws, even if the source state resigned from complete or partial taxation in accordance with legal provisions intended to enhance economic progress; or it may also grant exemption from its own tax of the (partially fictitious) amount calculated according to a higher rate in exchange for a reduction in taxation offered by the source state and exempt income that profited from the tax incentives in the source state [Kudert, Jamroży: 11].

Some countries (usually but not always developing ones) endeavor to attract foreign investors by lowering the rate of withholding tax on dividends, interest, and royalty payments below the level stipulated in international treaties. If such a country enters into an AADT with a developed country that uses the method of tax exemption as a measure for avoiding double taxation, there is no limit on the tax exemption for investors from the contracting state because that state must exempt from tax the investor's income generated in the second country, regardless of whether it has been taxed in that country.

The tax-exemption method is the most commonly adopted with respect to direct investments (e.g., investments made by subsidiaries). If a developed country uses the taxcredit method as a measure for avoiding double taxation, actual avoidance of taxation of income generated in the developing country will not occur. In such a case, the developed country will only allow exemption of tax actually paid in the source state of the income. In extreme cases, adoption of the tax-credit mechanism results only in an alteration of the place of income taxation and not an effective tax reduction, which may annihilate the effects of tax incentives provided by the state that is the source of the income [Hamaekers 2006: 147-148].

The primary advantage of the tax-sparing credit mechanism is the possibility of crediting tax that has not been paid in the income's source state against tax that will be payable in the state where the beneficiary of that income resides. The simplest and most effective use of tax sparing is in the relationship between two entities associated on a cross-border level. However, a given company might prefer to use available funds to finance an investment by an entity from a country that has not included the tax-sparing credit in an AADT with a state where the potential lender resides [Kudert, Jamroży: 14-15]. In such a case, it might be useful to establish or involve an intermediary entity that would be a tax resident of a state that uses the tax-sparing credit mechanism.

In conclusion, I believe that the tax-sparing credit mechanism may be successfully employed to optimize the tax liabilities of entities that conduct cross-border business activity. Solutions that lead to a tax reduction based on the tax-sparing credit are used for interest, dividends, and royalty payments. One must note, however, that using the taxsparing credit will not be possible in every case. Neither will a sole tax-sparing clause in an 
AADT always be sufficient to achieve a positive tax-related effect. Another significant issue is a "friendly" tax system in the source state of investment. An important element taken into account when implementing the tax-sparing credit mechanism is the approach taken by the tax authorities both in the source state of income and in the investor's state of residence, especially with respect to using clauses intended to prevent both circumvention of the law and treaty shopping.

In recent years, the practice followed has shown that EU Member States have become more cautious in implementing the tax-sparing credit mechanism into their AADTs. Until now, the primary reason to include these clauses in AADTs was the need to support economic development in the so-called developing counties. Nevertheless, some countries that not long ago were considered to be developing have recently achieved a high level of development. Some of these states have already achieved a level of development that is equal to or sometimes even higher than in the states that originally agreed to implement the tax-sparing clause. For that reason, the basic purpose for which the tax-sparing clauses were contained in AADTs has become outdated ${ }^{1}$.

An equally important reason to grant tax benefits that prompts developing countries to decide to implement the tax-sparing clause is that such a clause may attract foreign direct investments. One must remember, however, that the tax-sparing mechanism may also have the opposite effect. In practice, the clauses encourage foreign investors to transfer more profit earned in a given country to the state of the investor's residence than they reinvest to expand their existing investment and to spur further economic development in the source state of income. In effect, the tax-sparing mechanism upsets the balance between the need to attract new investments and the need to encourage investors who are already conducting activity in the income's source state to reinvest that income.

One must also remember that one of the basic assumptions of the tax-sparing concept is the fact that the state of the investor's residence loses part of its income by granting a tax credit for tax that was never paid in the income's source state, which is intended to cause the eventual taxation in the investor's state of residence of the income generated from such a tax benefit. Even if no tax-sparing clause is contained in an AADT, companies maximize tax benefits in an attempt to either avoid or defer tax. Consequently, taxation in the state of an investor's residence may never take place or it may occur many years later.

The tax-sparing clause receives increasing criticism owing to the fact that greater and greater awareness builds up of the abundant possibilities that these clauses contained in AADTs offer with respect to tax planning and tax avoidance. The tax-sparing clause may be used inconsistently with its original purpose by tax residents of a state granting it or tax residents of third countries may employ this clause through an entity with a registered

\footnotetext{
${ }^{1}$ I.e. Agreement between Cyprus and Portugal.
} 
office in the state accepting the tax-sparing clause. The costs of such tax-avoidance schemes for to countries that include the tax-sparing credit clause in their AADTs and to third countries whose residents benefit from the clause by treaty shopping may be enormous [Hamaekers 2006: 147-148].

\section{Advance pricing agreements}

Holding companies that seek tax optimization should precede their transfer-pricing decision process with a thorough analysis of market data (so-called price benchmarking). If a transfer price is "endangered", an entity must perform the following comprehensive analyses: a functional analysis primarily intended to indicate the actions, risk and assets involved in a transaction; a cost analysis involving costs that arise in connection with a transaction; and an analysis of anticipated benefits. The importance of systematically retaining source documents proving that service has been rendered, providing that a cost has been incurred, or attesting to market conditions cannot be overestimated [Schmidt, Jamroży, Scharf 2002: 422-423].

Advance Pricing Agreements (APAs) are an attractive tool for holding companies seeking international tax optimization and tax-related risk management connected with transactions between associated companies. Many EU Member States regulate APAs ${ }^{2}$. In many other states, despite the lack of legal provisions related to APA, the practice of using them has developed anyway [Błażejewska-Gaczyńska, Nowak 2005: 30]³. European countries' proposed solutions are principally in line with the OECD Guidelines on Transfer Pricing for Multinational Enterprises and Tax Administrations [Błażejewska-Gaczyńska, Nowak 2005: 31]. The essence of an APA is a formal agreement between a taxpayer and the tax administration of a given state concerning the choice and use of the transfer-pricing method. Its primary purpose is to eliminate the potential risk of double taxation and to avoid possible transfer-price-related disputes between the taxpayer and tax authorities. Capital companies that form international holding structures often use APA solutions.

The OECD guidelines distinguish among three types of APAs: unilateral (concluded between the taxpayer and its tax authorities), bilateral, and multilateral (i.e., agreements concluded by at least two states).

$\mathrm{Bi}$ - and multilateral agreements are negotiated by tax administrations in countries in which the taxpayers-parties to controlled transactions and who are interested in the agreement have their registered offices. A bilateral APA is based on a single mutual agreement between the appropriate tax bodies of two tax administrations. In contrast, a multilateral agreement is achieved as the result of multiparty negotiations among all of the interested tax administrations after a series of separate but mutually consistent bilateral agreements

\footnotetext{
${ }^{2}$ Great Britain, France, Netherlands, Belgium, Spain, Austria.

${ }^{3}$ Germany, Sweden, Ireland, Luxemburg.
} 
between the tax administrations of individual states where the interested taxpayers-parties to transactions have their registered offices.

From the perspective of international holding companies, entering into bi- and multilateral agreements is advantageous because each party to a transaction becomes certain of the appropriateness of a company's selected and used transfer-pricing method, and the risk of double taxation is limited.

Many countries' experiences [Błażejewska-Gaczyńska, Nowak 2005: 32] point to the conclusion that resolving transfer-pricing disputes through either traditional verification or the use of control techniques often is complicated and costly both for taxpayers and tax administrations, both with respect to the time involved and invested funds. Those techniques inevitably lead to analyses of the transfer prices already in use, along with the conditions under which they have been set. However, obtaining all of the information about the conditions under which prices have been established is often impossible during the control phase. This means that it might be difficult to reliably assess whether partiesassociated entities used the arm's-length principle when setting prices. To some extent, this situation has led to the practice of concluding APAs, which constitutes an alternative method of solving the transfer-pricing problem.

Accordingly, the primary purpose of concluding APAs is avoiding possible transfer-pricerelated disputes between taxpayers and tax authorities. Whereas if the concluded agreements are concerned with taxpayers-parties to transactions that have registered offices in different tax jurisdictions (international holding companies), the aim of an APA is to eliminate the risk of double taxation. This is because the amount of a taxpayer's income adjusted upwards by tax authorities as a result of questionable transfer prices could be subject to taxation in at least two tax jurisdictions, i.e., in the state where income was initially allocated based on the transfer prices set by the parties and where that income was taxed, and in the state where tax authorities have made the adjustment. Therefore, the aim of the agreements is to ensure appropriate and-of greater significance-predictable tax treatment of a taxpayer or taxpayers.

One must remember that not all EU Member States have implemented appropriate legal provisions concerning Advance Pricing Agreements. Some EU Member States have domestic legal regulations that govern the procedure for concluding APAs [Ernst\&Young $2003]^{4}$. Nevertheless, the mere lack of domestic regulations in this respect does not prevent interested taxpayers residing in those countries from being parties to bi- or multilateral pricing agreements. Such a possibility is offered to them by the mutual agreement procedure arising out of the OECD $\mathrm{MC}^{5}$ along with certain provisions of bilateral AADTs,

\footnotetext{
${ }^{4}$ I.a. In: Great Britain, France, Netherlands, Belgium, Spain, Austria.

${ }^{5}$ Art. 25 of OECD Model Tax Convention.
} 
if a party to one is a state where a given taxpayer has a registered office. There are countries [Ernst\&Young 2003] ${ }^{6}$, however, where the mutual agreement procedure is not formalized, but it is still used in practice based on the OECD $\mathrm{MC}^{7}$. There are also states in which the objective of an APA may be at least partially achieved by obtaining a binding interpretation from the tax authorities concerning the selected taxpayer's methodology for setting transfer prices [European Comission 2002]. In the last case, however, the aim of avoiding double taxation may not always be fulfilled because such a binding interpretation is not the result of consultation with the tax authorities of the second country.

One must also remember that those binding interpretations are concerned with interpreting legal provisions with respect to one particular taxpayer's situation. When making an interpretation regarding, for instance, the correctness of the applied method for the calculation of transfer prices in a given situation presented by the taxpayer, tax authorities analyze the legal circumstances and not-in contrast to APAs-the actual situation. Therefore, as opposed to APAs, binding interpretations do not offer, in principle, any flexibility with respect to the situation that is the basis for making an interpretation and do not entirely exclude the possibility of the tax authorities using methods to verify transfer prices that are different from the methods adopted in the interpretation. Thus, the interpretation that the taxpayer receives does not sufficiently ensure that the adopted method will not be questioned by tax authorities during a tax audit after a given situation has been thoroughly analyzed by the inspection bodies.

The forms of APAs preferred by the OECD are bi- or multilateral agreements. Based on practice and the OECD Guidelines, it must be stated that unilateral APAs are a partial solution that confirms the appropriateness of the taxpayer's method for calculating transfer pricing only for local transactions that fall under such an agreement. This solution does not offer certainty about the attitude that tax authorities of other interested states will have toward the adopted method. Therefore, adopting such a solution does not limit the potential risk of double taxation.

Following the OECD Guidelines, legislators of particular states ${ }^{8}$ prefer bi- or multilateral agreements. Clearly, unilateral agreements may be used simultaneously. This is because entering into bi- or multilateral agreements does not prevent entities from concluding unilateral agreements.

The EU Member States' procedures for entering into APAs are primarily based on the OECD Guidelines and require involvement of both the taxpayer and the appropriate tax administrations. Effective cooperation between them guarantees that the procedure will

\footnotetext{
${ }^{6}$ Germany, Sweden, Ireland, Luxemburg.

${ }^{7}$ Art. 25 of OECD Model Tax Convention.

${ }^{8}$ I.a. in: the Netherlands, France, Great Britain.
} 
end in success, i.e., in concluding an agreement that is satisfactory to all of the interested parties.

The scope of the procedure is different for bi- or multilateral agreements versus unilateral APAs. This is a consequence of the form of these agreements. Unilateral agreements comply with conditions established the domestic tax administration, whereas bi- and multilateral agreements are based mutual agreement as defined in the OECD MC and the applicable convention on avoiding double taxation; they are also concluded at the discretion of the appropriate tax administrations.

The procedure of mutual agreement also provides positive grounds for concluding APAs with parties that are residents of countries whose domestic laws do not provide for such agreements. Indeed, in line with the OECD Guidelines, such an agreement would be legally binding on both states and establish rights for the interested taxpayers [Guidelines 2004]. One must remember, however, that the OECD $\mathrm{MC}^{9}$ (along with the relevant provisions of the APAs) does not oblige the appropriate tax authorities to enter into bi- or multilateral APAs on a taxpayer's request. Readiness to enter into APAs based on this procedure depends on the policy pursued by a given state, along with how it interprets the provisions of bilateral conventions related to mutual agreements [Kubińska, Olejnik 2004: 23-24].

When entering into an APA, both the taxpayers and the tax authorities endeavor to obtain certain benefits. The basic advantage of an APA is that the taxpayer (for a specified period of time) gains certainty with respect to the tax consequences related to transactions between associated entities, which are covered by the agreement.

The certainty of a taxpayer's methodology allows tax liabilities to be predicted and limits the risk of potential fines. Entering into APAs also allows both the taxpayers and the tax authorities to avoid costly and time-consuming transfer price audits, the results of which can be predicted neither by the taxpayer nor the inspection bodies.

$\mathrm{Bi}$ - and multilateral agreements eliminate the risk of legal or economic double taxation.

Nonetheless, the APA procedure requires the taxpayer to disclose commercially sensitive information. Accordingly, the taxpayer might feel anxious that the disclosed information and data will be used in a tax audit, if an agreement with the tax authorities is not concluded. The OECD Guidelines clearly state that information disclosed during negotiations should be protected. In other words, such information should not be used as evidence in future or ongoing tax proceedings. However, the experience of countries using APAs suggests that the range of information disclosed by taxpayers is narrower than that disclosed during a tax audit.

\footnotetext{
${ }^{9}$ Art. 25 of OECD Model Tax Convention.
} 
Practice shows that the APA procedure is usually time-consuming and costly for both taxpayers and tax authorities. High costs are primarily related to the necessity to perform appropriate market analyses, which are often commissioned by external experts.

Usually, APAs involve drawing on substantial financial funds that are primarily provided by a tax administration. To obtain a correct result, an APA should ensure that administrative staff are appropriately qualified to address transfer pricing. Therefore, considerable costs brought about by the APA procedure forces fiscal authorities to limit the number of APA requests that will be examined. Consequently, tax authorities primarily focus on examining requests filed by large taxpayers (usually holding companies) and that relate to complicated and serious transactions. As a result, there is only a limited possibility of minor taxpayers entering into APAs [Comission 2001; Gajewski 2012: 45].

Practice shows that APAs offer certain benefits both to taxpayers and tax authorities. The advantages of APAs have been noticed by the EC, which supports their implementation and development in all EU Member States. The desire to benefit from the privileges offered by such agreements encourages more and more countries to include provisions on APAs in their statutes.

The fact that many EU Member States have domestic regulations regarding the procedure for entering into and using APAs may be helpful in creating legal provisions concerning APAs in the states where there is no legal basis for such agreements. If other countries' experience is followed, potential mistakes could be avoided, thus contributing to creating a system that guarantees benefits to both taxpayers and tax administrations.

It is undeniable that entering into an advance pricing agreement most certainly results in the benefit of tax authorities not questioning the price of transactions among companies forming a holding structure. It is worth entering into such agreements, especially if there is a concern about repeatable transactions being part of a holding company's basic business activity, the value of which constitutes a substantial proportion of a company's revenue, or in the case of specific transactions, involve intangible assets of considerable value.

\section{Conclusions}

A holding company's tax optimization achieved by pursuing the right capital-company tax policies has become a standard economic reality. It is the very optimization of tax strategies, especially on an international scale, which makes it possible for groups of companies to achieve substantial financial savings. European holding companies are increasingly willing to use external sources of finance (on capital markets) or to take loans from banks. Therefore, if such a strategy is followed by a holding company, a rational taxoptimization policy is necessary. 
Transfer pricing has always been an element of tax optimization, although it has also caused disputes among tax authorities. Appropriately set transfer prices must be reflected in tax planning. Although free shaping of transfer prices between associated entities is generally structured by the arm's-length principle, that does not mean that there are stiff price brackets. The correct distribution of the factors that influence a transaction (such as the entailed risk, adopted economic strategy) make it possible to establish prices for transactions between associated entities at the desired level. An APA may be employed as a tax-optimization tool in this respect. An APA is an important instrument that influences the shape of tax-optimization policies pursued by international holding companies (with respect to transfer-pricing policies). APAs eliminate or significantly limit legal and economic double taxation (or lack of taxation), if all of the relevant countries are involved. Unilateral APAs do not offer certain reductions in double taxation because tax administrations influenced by the transactions covered in an APA may decide that the assumed methodology does not have a result consistent with the arm's-length principle. However, bi- and multilateral APAs may improve the procedure for mutual agreement by considerably reducing the time required to reach an agreement because the appropriate bodies use current data instead of data from the previous year, which might be difficult or time-consuming to demonstrate.

International holding companies' tax planning often involves the joint use of several instruments: a tax-sparing credit, an APA, a hybrid instrument, and thin capitalization. These instruments are hermetically interrelated. In effect, they may jointly form an effective tax-avoidance strategy that has a substantial likelihood of avoiding questions by tax jurisdictions in particular EU Member States. One must note that tax statutes are usually prepared to counter holding companies' policies, if those policies are based on the use of the instruments presented above and are used separately (not jointly). If an international holding company introduces several of these instruments into its strategy and acts in various tax jurisdictions (i.e., if it acts within different systems that counter tax avoidance), working against the negative consequences that follow will not succeed. Thus, international holding companies' creation of a complex tax architecture leads to the emergence of the phenomenon of tax erosion in the EU Member States with the leastpreferential tax systems.

\section{References:}

Błażejewska-Gaczyńska A., Nowak A.: Analiza polskich uregulowań o APA w kontekście przepisów i praktyki wybranych krajów Unii Europejskiej [Analysis of Polish Regulations on APA In the Context of Laws and Practices European Union Countries], Przegląd Podatkowy [Tax Review] vol. 15, no. 12 (2005) 
Gajewski D.: The Role of Hybrid Instruments in the Implementation of Business Tax Policy, Contemporary Economics, vol. 6, no. 2 (2012)

Hamaekers H., In: Hamaekers H., Holmes K., Głuchowski J., Kardach T., Nykiel W., Wprowadzenie do międzynarodowego prawa podatkowego [Introduction to International Tax Law], Warsaw: LexisNexis, 2006

Kubińska J., Olejnik K.: Uprzednie porozumienia cenowe [Advanced Pricing Arrangements], Przegląd Podatkowy [Tax Review] vol. 14, no. 3 (2004)

Kudert S., Jamroży M.: Polityka wykazywania dochodów a optymalizacji opodatkowania [Policy of Revealing Incomes and Tax Optimization], Przegląd Podatkowy [Tax Review], vol. 13, no. 5 (2003)

Kudert S., Jamroży M.: Rozliczenie strat a optymalizacji opodatkowania [Calculating Losses and Tax Optimization], Przegląd Podatkowy [Tax Review] vol. 14, no. 11 (2004)

Scheuneumann M.: Decision In the Marks\&Spencer Case: A step Forward, but No Cictory for Cross-Border Group Taxation In Europe, Intertax vol. 34, no. 2 (2006)

Schmidt Ch., Jamroży M., Scharf M.: Verrechnungspreisgestaltung bei Leistungsbeziehungen zwischen inlandischen Unternehmen und Iren polnischen Tozhterkapitalgesellschaften, IStR, 2002

Williamson S.: Thin Capitalization: Critical Review, Australian Tax Forum vol. 8, no. 2 (1991)

\section{List of documents:}

Background Document on the Replies Received from Member States to the Questionnaire on the Application of Transfer Pricing Rules and Arbitration Convention, Brussels 2002 .

Commision of the European Communities, Brussels 2001.

Transfer Pricing 2003. Global Survey, Ernst\&Young.

Wytyczne w sprawie cen transferowych dla przedsiębiorstw wielonarodowych oraz administracji podatkowych [Guidelines on Transfer Pricing for Multinational Corporation and Tax Administration], Warsaw, 2004 